\title{
uma depois da outra
}

primeiro a neve.

após a última neve

o primeiro parto.

após o último pós-parto

a primeira comunhão.

após a última porcaria

o primeiro amor.

após a última palavra

a primeira hipoteca.

após o último centavo

a primeira guerra mundial.

após o último alistamento

a primeira procuradoria.

após a última instância

o primeiro nurembergue futebol clube.

após a última camisa

o primeiro socorro.

após a última burrada

o primeiro violino. 
após a última honraria

o primeiro canto do galo.

após a última merda

por último

a primeira neve. 